\title{
A sztrájkjog közszférában történő gyakorlásának korlátai és lehetőségei
}

\section{HRECSKA-KOVÁCS RENÁTA}

A közszférában dolgozók minden jogállamban bizonyos fokú korlátozásokkal gyakorolhatják a sztrájkhoz való jogukat, hiszen az állam funkcióit fôszabály szerint nem béníthatja meg egy-egy tiltakozásképpen szervezett munkabeszüntetés. A sztrájkjog dogmatikájának kialakításában ezért nemzetközi szinten mindig kérdéses volt, hogy hol húzható meg a szükségesség és arányosság azon határa, amely szerint az érintett munkavállalók még képesek élni az alapvetô érdekérvényesítési lehetőségeikkel, ugyanakkor nem fordulnak szembe a közszolgálat ethoszával, és az elvárt lojalitás szerint képesek elvégezni a munkájukat. A közhivatalokban sztrájkot hirdetni nagy körültekintést igényel, ezért fontos kérdésként merülhet föl az is, hogy a szakszervezetek automatikusan rendelkeznek-e ilyen jogosultsággal, vagy felmerül olyan többletkritérium, amelynek meg kell felelniük a sztrájk megszervezéséhez.

\footnotetext{
Hrecska-Kovács Renáta

Mádl Ferenc Összehasonlító Jogi Intézet

e-mail: renata.hrecska@mfi.gov.hu
}

Hrecska-Kovács, R. (2021) 'A sztrájkjog közszférában történő gyakorlásának korlátai és lehetőségei’ in Szilágyi, J.E., Hrecska-Kovács, R. (szerk.) A sztrájkjog összehasonlító jogi elemzése egyes európai államokban, 103121. o. Budapest: Mádl Ferenc Összehasonlító Jogi Intézet. 


\section{Miért korlátozzuk a közszférában a munkabeszüntetés lehetőségét?}

Bár a sztrájkhoz való jog széles körben elismert jognak minősül, hiszen levezethető többek között az emberi méltóságból, a munkához való jogból, a véleménynyilvánítás szabadságából, az egyesülési szabadságból, az egészséghez való jogból, indokolt esetekben korlátozása vagy tilalma nem sérti az Emberi Jogok Európai Egyezményét, ${ }^{1}$ sem semmiféle egyéb nemzetközi emberi jogi egyezményt. Így a közszférában gyakorlatilag minden jogállamban vagy korlátozásokkal lehetséges sztrájkot szervezni, vagy pedig teljes tilalom érvényesül.

Magyarországon a szabályozás elsődleges forrásaként funkcionáló Alaptörvény kerüli a sztrájk fogalmának használatát, ${ }^{2}$ és tényleges iránymutatást sem tartalmaz arra nézve, hogy pontosan kiket illet meg ez a jog. Hazánkban a sztrájkról szóló 1989. évi VII. törvény kísérli meg röviden szabályozni az idetartozó érdekérvényesítési lehetőségeket. A törvény szerint nincs helye sztrájknak az igazságszolgáltatási szerveknél, a Magyar Honvédségnél, a rendvédelmi, rendészeti szerveknél és a polgári nemzetbiztonsági szolgálatoknál. ${ }^{3} \mathrm{Az}$ államigazgatási szerveknél a Kormány és az érintett szakszervezetek megállapodásában rögzített sajátos szabályok mellett gyakorolható a sztrájk joga, de a Nemzeti Adó- és Vámhivatalnál a hivatásos állományúak nem jogosultak a sztrájkjog gyakorlására. Emellett nincs helye sztrájknak, ha az az életet, az egészséget, a testi épséget vagy a környezetet közvetlenül és súlyosan veszélyeztetné, vagy elemi kár elhárítását gátolná. ${ }^{4}$

Bár az államokban általános gyakorlat, hogy bizonyos jogalanyi körben a sztrájkjog gyakorlása korlátozást szenved, Nathalie Merley francia szakértő álláspontja szerint a közszféra sztrájkjogának alkotmányos értékét gyengíti a közigazgatási ítélkezési gyakorlat azáltal,

1 Beauregard, 2019, 625. o. „Die Verfassungsrichter, die ihrer Entscheidung freilich das Grundgesetz als primären Prüfungsmaßstab zugrunde zu legen hatten, kamen im Einzelnen zu folgenden Feststellungen:

1. Beamte sind vom persönlichen Schutzbereich des Art. 9 III GG erfasst.

2. Das Streikverbot für Beamte ergibt sich aus Art. 33 V GG (Grundsatz des Berufsbeamtentums) und insbesondere aus den Prinzipien der Alimentation, der Treue, der Tätigkeit auf Lebenszeit und der Regelung der Rechtsverhältnisse durch Gesetz.

3. Diese Auslegung widerspricht nicht der EMRK, wobei dahinstehen kann, ob schon kein Verstoß vorliegt oder ein solcher gerechtfertigt wäre.

2 A XVII. cikk (2) bekezdése csupán annyit rögzít, hogy a törvényben meghatározottak szerint a munkavállalóknak, a munkaadóknak, valamint szervezeteiknek joguk van ahhoz, hogy érdekeik védelmében együttesen fellépjenek, amely magában foglalja a munkavállalók munkabeszüntetéshez való jogát. Bár korábban a szakirodalom egy része kiemelte (ld. pl. Rácz, 2012, 575. o.), hogy az Alaptörvény szövegezése a munkaadók számára is lehetôvé teszi a munkabeszüntetést - azaz az egyébként illegális kizárás jogának gyakorlását az Alaptörvény egyértelmúen csak a munkavállalók részére engedélyezi a munkabeszüntetés lehetőségét.

3 A rendvédelmi szerveknél folytatható sztrájkjog gyakorlásával kapcsolatban nemzetközi kitekintést is tartalmaz: Pajcsicsné Csóré és Varga, 2009, 91-98. o.

4 1989. évi VII. törvény, 3. \$ (2)-(3) bekezdések. 
hogy továbbra is elismeri a korlátozásra irányuló szabályozási intézkedések jogszerúségét. 5 Teszi mindezt annak ellenére, hogy a kérdés alkotmányos és jogalkotási szabályainak erőteljes fejlődésének lehetünk tanúi az utóbbi időkben több olyan ágazatban, ahol a jogalkotó beavatkozott és korlátozza e jog gyakorlását. ${ }^{6}$ Ezzel kapcsolatban érdekes árnyalatot, vagy akár cáfolatot jelenthet, hogy a nemzetközi gyakorlatot vizsgálva általában a sztrájkjog vonatkozásában nem a jog tartalmának, hanem sokkal inkább a sztrájkra jogosultak személyi körének a korlátozásáról van szó.

Mindenesetre a témában több lényeges mozzanatra került sor: Az egyik komoly előrelépés a European Confederation of Police (EuroCOP) v Ireland, 83/2012. számú ügy7 kapcsán történt, ahol az Európa Tanács Szociális Jogok Európai Bizottsága kimondta, hogy a rendőröket érintő abszolút sztrájktilalom sérti az Európai Szociális Chartában foglaltakat, hiszen nem igazolható az alátámasztott érdek, amelyet a munkabeszüntetés teljes mellőzése árán védeni kell. Európában ehhez képest meglehetősen ritka, hogy a rendőrség sztrájkolhasson, de például Belgiumban tilalom helyett azzal a megkötéssel gyakorolható a sztrájkhoz való jog, hogy a munka beszüntetése eloott a felek megpróbálnak békés megoldásra jutni, azaz tárgyalási kötelezettség előzi meg a sztrájkot. ${ }^{8}$

A rendőrség mellett az ügyészség is általános tilalom alá esik, Dániában azonban egy érdekes jogtechnikai megoldással alapozták meg az érintett személyi csoport sztrájkjogosultságát: a köztisztviselők bizonyos kategóriáit különleges bizalmi kapcsolat köti, és teljesen tiltják számukra a sztrájkot, 2012 óta azonban a rendőrségi helyettes ügyészeket, az ügyészeket és az államügyészeket egészen egyszerủen nem tekintik köztisztviselőknek, és ezért most rendelkeznek sztrájkjoggal.

A közszférában a jelenlegi gyakorlatok szerint a sztrájkjog gyakorlása három aspektusból korlátozható. Egyfelől bejelentéshez köthető a sztrájk megkezdése,? ezzel a jogalkotó el kívánja kerülni a meglepetésszerủen induló munkabeszüntetéseket. Könnyen belátható, hogy a közszférában rendkívül rövid idő leforgása alatt nehezülhetne el a hivatali múködési mechanizmus, illetve az állampolgárok helyzete, ha a munkabeszüntetés nem szervezett körülmények között zajlana le. Másfelől a jogalanytól elvonható a sztrájkhoz való jog - ezzel teljes és általános sztrájktilalmat vezet be a jogalkotó bizonyos személyi csoportokra nézve. ${ }^{10} \mathrm{~A}$ harmadik megoldás a sztrájk eredményességét csökkentheti, de az állami hivatalok megszakí-

5 A kollektív érdekvédelmet és a közös fellépés lehetőségeit bizonyos változások, átalakulások és jelenségek folyamatosan erodálják, a tilalmak túl feszes kikényszerítése mellett a szakszervezeti szervezettség jelentôs csökkenése is hozzájárulhat a helyzet elnehezüléséhez. Berki Erzsébet a hazai folyamatokra több múvében is rámutat (pl. Berki, 2019, 5. o.).

6 Merley, 2017, 66. o.

7 Council of Europe: Processed Complaints (https://cutt.ly/YxoDygF).

8 Ld.: https://www.epsu.org/article/right-strike-public-sector-europe (Which workers are denied the right to strike?).

9 Merley, 2017, 75. o.

10 Merley, 2017, 76. o. 
tatlan múködése érdekében indokolt lehet: a munkáltatói jogkör gyakorlója dönthet úgy, hogy a sztrájkoló munkavállaló helyére ideiglenesen új munkaerőt alkalmaz átszervezés útján. ${ }^{11}$

Összefoglalva, úgy látszik, hogy bár a sztrájkjog erôsítése terén történtek előrelépések, a közszférában nemzetközi összehasonlításban általános sztrájktilalom érvényesül a belbiztonsági ügynökségek, a belső hírszerző szolgálatok, a katonai hírszerző szolgálatok, a korrupcióellenes központi hivatalok, a rendőrségek, a börtönigazgatási szolgálatok, a határőrségek, a tûzoltóságok, a mentők, az állami szervek, a bíróságok és ügyészségek alkalmazottai ${ }^{12}$ számára. ${ }^{13}$

A témában érdemes áttekinteni a német alkotmánybíróság (Bundesverfassungsgericht) ítélkezési gyakorlatát, amelynek eredményei szerint alkotmányosnak minősül a közszolgálatot ellátó alkalmazottakra (különösen a tanárokra) vonatkozó sztrájktilalom. A német alkotmánybírák megállapították, hogy a közszolgálati tisztviselők az alkotmány (Grundgesetz) 9. cikk (3) bekezdésének hatálya alá tartoznak, ugyanakkor a sztrájktilalom levezethetô a 33. cikk (5) bekezdéséből, ${ }^{14}$ különösen az alimentáció elvéből, a hűségklauzulából, az élethivatásszerűségből, valamint a jogviszonyok törvény általi szabályozottságából.

Lengyelországban szintén egy alkotmánybírósági döntés segít eligazodni a közszolgálat helyzetében: a K 5/15. számú döntés ${ }^{15}$ értelmében nem minősül alkotmányellenesnek, hogy nem köthető kollektív szerződés a köztisztviselőkre, az állami és az önkormányzati hivatalnokokra, valamint a bírákra, ülnökökre és ügyészekre vonatkozóan. ${ }^{16} \mathrm{Az}$ alkotmánybíróság szerint a szakszervezetek kollektív szerződés megkötéséhez való joga nem abszolút jellegű jog, ebből kifolyólag - Alkotmányban előírt esetekben - korlátozható. A kollektív szerződésekhez hasonló elbánást kap a sztrájkszabályozás is. A lengyel Alkotmány ${ }^{17} 59$. cikk (3) bekezdése szerint „[a] szakszervezeteknek jogukban áll a munkavállalók sztrájkját vagy más tiltakozását megszervezni a törvényben meghatározott keretek között. A közérdek védelme érdekében törvény korlátozhatja vagy megtilthatja a sztrájk egyes formáit a munkavállalók speciális csoportjára nézve vagy speciális területeken." Ennek alapján a kollektív munkaügyi viták rendezéséről szóló törvény ${ }^{18}$ (Collective Labour Dispute Resolution Act, a továbbiakban: CLDRA) 19. cikke rendelkezik a sztrájk kizárásának eseti köréről. Az (1) bekezdés szerint az állam biztonsága érdekében tilos a munkaleállás azon a munkahelyen, eszközön és beren-

11 Merley, 2017, 77. o.

12 A felsorolás Mélypataki Gábor adatgyüjtése alapján táblázatos formában megtalálható: Mélypataki, 2018, 138. 0 .

13 Kisebb kiegészítésekkel ezt a mintát követi például Lengyelország, Szlovákia vagy Csehország.

14 Grundgesetz, Art. 33 (5): „Das Recht des öffentlichen Dienstes ist unter Berücksichtigung der hergebrachten Grundsätze des Berufsbeamtentums zu regeln und fortzuentwickeln."

15 Varsó, 2015. november 17.

16 Ustawa z dnia 26 czerwca 1974 r. Kodeks pracy. - munka törvénykönyve 239. cikk (3) bekezdés.

17 A törvény címe és hivatkozása eredeti nyelven: Konstytucja Rzeczypospolitej Polskiej z dnia 2 kwietnia 1997 r., Dz. U. z 1997 r. Nr 78, poz. 483. http://www.sejm.gov.pl/prawo/konst/angielski/kon1.htm.

18 A törvény címe és hivatkozása eredeti nyelven: Ustawa z dnia 23 maja $1991 \mathrm{r}$. o rozwiązywaniu sporów zbiorowych, Dz.U. z 1991 r. Nr 55, poz. 236. 
dezésen, amelyen a munkából való tartózkodás veszélyezteti az emberi életet és az egészséget vagy az állam biztonságát. Ez a meghatározás minden államban egyfajta vezérfonalként van jelen, és nyilvánvalóvá teszi azt is, hogy miért ennyire jelentős kérdés a közszférában szervezett sztrájk: szinte alig található olyan pozíció, amelynek nincs legalább közvetett hatása az alkotmányosan védett értékek valamelyikére, így a munkabeszüntetés állandó mérlegelésre kényszeríti a jogalkotót, a résztvevőket, illetve a sztrájk jogosságának elbírálóit is.

Szlovákiában 2002-ben vált el egymástól az állami és magánszféra, azóta vannak hatályban a két területen eltérő szabályok a foglalkoztatás és a munkaügyi kapcsolatok területén. Az államigazgatási alkalmazottak, valamint a területi önkormányzati tisztségviselők esetében a sztrájkhoz való jog, a fegyveres erók és fegyveres testületek esetében petíciós jog és a békés gyülekezés joga is törvénnyel korlátozhatók, ha azok összefüggenek a szolgálatteljesítéssel. A lengyel szabályozáshoz hasonló rendszer alakult ki annyiban, hogy azoknak a személyeknek, akiknek foglalkozása feltétlenül szükséges az élet- és egészségvédelemben, a sztrájkjoga korlátozható. ${ }^{19}$

Jó példaként szolgál erre a kitételre a pozsonyi orvosok 2006 áprilisában tartott sztrájkja, amelynek célja a kórházak privatizációja elleni tiltakozás, illetve egyúttal 25\%-os béremelés volt. A bíróság határozatban tiltotta be a sztrájkot, indoklása szerint a sztrájkolók azért nem folytathatták tovább a munkabeszüntetést, mert az emberek egészségét és életét sodorták veszélybe. A sztrájkoló orvosok és ápolók bejártak ugyan a munkahelyükre, de csak az életmentő és a sürgősségi beavatkozásokat végezték el, betegségmegelőző vizsgálatokat nem végeztek, és a várólistás betegeket sem mútötték meg. ${ }^{20} \mathrm{~A}$ szlovák orvosi szakszervezet elnöke úgy nyilatkozott, hogy a demonstráció sem Szlovákia alkotmányával, sem pedig az Európai Unió jogrendjével nincs ellentétben. ${ }^{21}$ Szlovákia esete nem egyedi abban a tekintetben, hogy hiába áll fenn egy sztrájktilalom, azt az érintett csoportok adott esetben akár következmény nélkül megszeghetik: Romániában az irányadó sztrájktilalom ellenére több esetben megtörtént, hogy bírók tüntettek bérük vagy nyugdíjuk módosítása érdekében ${ }^{22}$ de a börtönőrök szakszervezete is hirdetett meg sztrájkot.

A korlátozással érintett csoportok sorsát illetően fontos kitérni Csehország esetére, hiszen a Szociális Jogok Európai Bizottsága (European Committee of Social Rights - ECSR) 2018-ban a sztrájkból kizárt foglalkozások pontosítását kérte, mert a kizárás túlságosan széles kört érintett, és a sztrájkból való teljes kizárásuk nem volt indokolható, azonban ennek megváltoztatására 2019-ig nem került sor. ${ }^{23} \mathrm{~A}$ cseh jogrendszer hiányossága jelenleg az is, hogy nem került meghatározásra, mely szektorok és mely szolgáltatások tekinthetôk létfontosságúnak,

19 Ld. https://www.torvenytar.sk/pdfRules/1496651864_71_2017.pdf.

20 Érdekesség, hogy a megmozdulást egyébként a magyarországi orvosi kamara is támogatta.

21 Zemplényi, 2010.

22 Ilyenkor a sürgôsebb ügyek kivételével, halasztották a tárgyalásokat.

23 Balanescu, 2019.

Ld.: https://www.zakonyprolidi.cz/cs/2014-234?text=strike. 
és nem határozták meg a még elégséges szolgáltatás mértékét azokban a szektorokban, ahol korlátozott a sztrájk lehetősége. ${ }^{24}$

A teljesítés elvárt szintje egyébként egzakt módon nyilvánvalóan nem meghatározható, azonban kísérletek végezhetôk arra nézve, hogy legalább az egyes esetekben egyedileg megpróbálkozzon a bíróság egy zsinórmértéket adni. Magyarországon a még elégséges szolgáltatás mértékéről és feltételeiről a felek megállapodással dönthetnek, ${ }^{25}$ ennek hiányában a közigazgatási és munkaügyi bíróság a felek által megtett ajánlatok mérlegelésével, az egyik fél által tett végső ajánlat elfogadásáról rendelkező határozat meghozatalával dönthet, ${ }^{26}$ de törvény is rendelkezhet a mértékrool és feltételekről..$^{27} \mathrm{~A}$ dolog természetéből adódóan a teljességre törekvő szabályozás ellenére nem találunk általánosan alkalmazható mércét, azonban több fontos szempontot is figyelembe kell venni az adott helyzet megítélésekor:

A sztrájkjog gyakorolhatósága tekintetében a konkrétan megfogalmazott egyes sztrájkkövetelések alapján lehet dönteni. Amennyiben valamely követelés tekintetében megállapítható, hogy az a sztrájkot kezdeményezők gazdasági és szociális érdekei biztosítására irányul, és a sztrájkot a törvény kifejezetten nem tiltja, a sztrájkjog a munkavállalókat megilleti.

Természetesen e helyzetben is korlátozza a jog gyakorlását a még elégséges szolgáltatás követelménye. Annak megítélésekor, hogy mely tevékenység, szolgáltatás minősülhet alapvetô szolgáltatásnak, a munkáltató saját vagyonvédelmén és gazdasági érdekein túlmutató, a lakosságot közvetlenül és súlyosan érintő szempontokat lehet értékelni.

A kizárólag alapvető szolgáltatásnak minősülő tevékenység végzésére új munkavállaló határozott idejú felvétele nem eredményezheti a sztrájkjog csorbítását.

A fentieket mérlegelve felmerül a kérdés: amennyiben nem adjuk meg a jogot bizonyos személyi csoportok számára, hogy éljenek az igényérvényesítés sztrájk adta lehetőségével, akkor vajon mégis milyen úton jelezhetik a munkakörülményekkel kapcsolatos elégedetlenségüket? A megoldások széles skáláját ismerjük: Lengyelországban például a CLDRA nem nyújt alternatív eszközöket azon munkavállalók részére, akik számára nem garantálták az egyesülési jogot és/vagy a kollektív alkuhoz való jogot. ${ }^{28}$ Ezzel szemben Szlovákiában azokon a területeken, ahol tilos a sztrájk, a felmerüló munkaügyi vitákat csak döntőbíró (arbitrator) előtt lehet megoldani. A döntóbíróhoz az érintett felek közösen is fordulhatnak, de ha erről nem tudnak megállapodni, akkor bármelyikük kérheti, hogy a Munkaügyi, Szociális és Családügyi Minisztérium jelölje ki az ügyben eljáró döntőbírót. ${ }^{29}$ Általánosságban elmondható, hogy a sérelmet

24 Balanescu, 2019.

25 A témáról ld. részletesen: Berki, 2009, 111-118. o.

26 Kúria Közigazgatási-Munkaügyi Kollégiuma 1/2013.(IV.8.) véleménye (https://cutt.ly/ScHDRRB).

27 1989. évi VII. törvény, 4. \$ (3) bekezdés.

28 Świątkowski, 2018, 70. o.

29 Ld.: https://cutt.ly/5xoGC35. 
szenvedett felek a hagyományos igényérvényesítési eszköztárral élhetnek, azaz belső egyeztetéseket kezdeményezhetnek a vezetéssel, ezek eredménytelensége esetén pedig bizonyos alternatív konfliktusrendezési módszerek alkalmazása megfelelőnek tûnik a közszféra esetében is.

Az államoknak van egy olyan csoportja is, amely beépít valamilyen plusz feltételt a jog gyakorlásához, de nem zárja ki a közszféra sztrájkját, illetve olyat is találunk, ahol ezt a kérdést egyáltalán nem szabályozzák.

Előbbire példaként hozható Franciaország, ahol a közszféra részét képezik az állami alkalmazottak, a regionális önkormányzatok és 10000 fó lakosságszám feletti települések foglalkoztatotti állománya, illetôleg a közfeladatot ellátó magáncégek, szervezetek, intézmények munkavállalói is. Ebben az államban nincs tilalom, azonban a megjelölt alanyi körbe tartozó munkavállaló köteles a munkabeszüntetésre irányuló szándékát bejelenteni. A bejelentés formáját tekintve egy nemzeti, ágazati vagy munkahelyi szintú szakszervezettől érkezhet, és tartalmaznia kell a sztrájkra lépés okait. A sztrájk földrajzi és idóbeli vonatkozásait is tartalmazó nyilatkozatot az adott szervezet vezetőivel közölni kell a sztrájk kezdete előtt legalább öt nappal. A nyilatkozat közlésétől a sztrájk kezdetéig terjedő periódus során az érintett felek egymással kötelesek tárgyalni. ${ }^{30}$ Kritikaként érheti a francia szabályozást, hogy amennyiben a felek betartják az elôírt határidőket, úgy akár több mint két hétre is elhúzódhat a sztrájkot megelőző előkészítő időszak. A rendszernek köszönhetően nemcsak a sztrájkhoz való jog gyakorlása szorul bizonyos szempontból szükségtelennek érzett keretek közé, de a jogalkotó megakadályozza, hogy az érintettek olyan elöre nem látható eseményekkel szemben sztrájkkal lépjenek fel, mint amilyen például egy tanár bántalmazása. ${ }^{31}$

Olaszországban nincsenek külön korlátozások a köztisztviselők szakszervezeti jogaira nézve, csupán a rendőrség és a fegyveres erők irányában áll fenn tilalom. ${ }^{32}$ Amennyiben az elégséges szolgáltatás mértéke tekintetében vita merül fel a munkáltató és a szakszervezet között, a Garancia Bizottságnak ${ }^{33}$ kell megállapítania, hogy a vita tárgyát képező szolgáltatás mértéke megfelelö-e az adott közszolgáltatási szektor követelményeihez képest. ${ }^{34}$ A Bizottság határozatai megtámadhatók a Munkaügyi Bíróság előtt.. ${ }^{35}$

Ausztriában a fentiektől egészen eltérő szabályozás alakult ki: a köztisztviselők jogállásáról szóló törvény nem ismeri a sztrájk fogalmát, ${ }^{36}$ arra vonatkozó rendelkezést nem

30 Code du Travail, L2512-2. cikk.

$31 \mathrm{Ld}$. Saisine du Conseil constitutionnel en date du 25 juillet 2008 présentée par au moins soixante sénateurs, en application de l'article 61, alinéa 2, de la Constitution, et visée dans la décision n 2008-569 DC - I/B. (https://cutt.ly/GxoG7QG).

32 Clauwaert és Warneck, 2009.

33 Olaszországban a közvetítésnek nincsenek tradíciói, a Garancia Bizottság nem rendelkezik mediációs jogkörrel, azonban a felek kérésére elláthat arbitrációs feladatokat a minimum-szolgáltatás mértékében történő megállapodás kapcsán. (Ld.: Kajtár, 2011, 46. és 49. o.)

34 Berke és Kiss, 2009, 31. o.

35 Clauwaert és Warneck, 2009, 102. o.

36 Korábban az 1914. évi sztrájkrendelet a köztisztviselók sztrájkban való részvételét kifejezetten tiltotta és büntetőjogi szankcióval büntette. 
tartalmaz, így a gyakorlat és a szakirodalom formálja a közszférában előforduló sztrájkot. Közszolgálati tevékenység esetében a sztrájk korlátozása ${ }^{37}$ nem általános jellegú, hanem arra irányul, hogy a közszolgálatot teljesítő a munkaharci tevékenység során betartja-e hűségkötelezettségét, tevékenysége érint-e az állami tevékenységet. Amennyiben tevékenysége ezeket nem sérti, nem ütközik ezekbe a követelményekbe, úgy jogszerü a munkaharca. Ellenkező esetben büntetőjogi szankciót von maga után a köztisztviselő sztrájkban való részétele, méghozzá hivatali visszaélés búntette miatt. ${ }^{38}$

\section{Az államigazgatási szerveknél szervezett sztrájk egyedi szabályozása}

A sztrájkjog gyakorlása és a közszolgáltatásokhoz való hozzáférés alapjogok kollíziójaként, egymással való versengéseként határozható meg. ${ }^{39}$ Maina Kai szerint ${ }^{40}$ a kormány társadalmi és gazdasági politikájával, valamint a negatív vállalati gyakorlatokkal szembeni tiltakozás az alapvető polgári szabadságjogok részét képezi, amelyek tiszteletben tartása elengedhetetlen a szakszervezeti jogok értelmes gyakorlásához. Ez a jog lehetővé teszi számukra, hogy egyenlő feltételek mellett vegyenek részt a vállalkozásokkal és a kormányokkal való tárgyalásokban, és a tagállamoknak pozitív kötelezettségük van e jog védelme érdekében, és negatív kötelezettségük van arra, hogy ne zavarják annak gyakorlását. Hangsúlyoznunk kell, hogy a közszférában megkövetelt lojalitási kötelezettség egyáltalán nem jelentheti azt, hogy a tisztviselőnek vagy a közalkalmazottnak le kellene mondania a mindennapi életvitel biztosításához szükséges bérszínvonalról vagy munkafeltételekről: amennyiben ezen munkafeltételek fejlesztésre szorulnak, nem jelenti a lojalitás megszegését, ha érvényesíti érdekét az érintett munkavállaló. Amennyiben az érdekérvényesítés lépcsőfokain nem talál eredményt az adott személyi kör, akkor végső eszközként rendelkezésére állhat a sztrájk.

Ki kell emelnünk, hogy a sztrájkjog védelme nem pusztán az államok jogi kötelezettségeinek teljesítését jelenti. Arról is szól, hogy hosszú távon fenntartható demokratikus és méltányos társadalmakat hozzanak létre a kormányzatok, így a sztrájkhoz való jog a hatalomkoncentráció tulajdonképpeni ellenőrzését jelenti. Az alapjogi ütközések megfelelő kezelése, illetve így a demokratikus értékek megóvása érdekében a közszférában nemzetközileg ritka szabályozási eszköznek tekinthetjük a magyar kormányzat és az érintett szakszervezetek között a sztrájkról szóló 1989. évi VII. törvény 3. \$ (2) bekezdésének felhatalmazása alapján 1994-ben kötött sztrájkmegállapodást, amely az államigazgatási szerveknél szervezendő munkabeszün-

37 Stefan és Wiebke, 2009, 14. o.; Birklbauer, 2000; Mélypataki, 2018, 138. o.

38 Stefan és Wiebke, 2009, 14. o.

39 Lápossy és Zeller, 2009, 105. o.

$40 \mathrm{Az}$ ENSZ békés gyülekezés és egyesülés szabadságával foglalkozó rapportőrje - az ILO irányító testületének 2017. évi 329. ülésén tartott beszédében hangzott el a sztrájkhoz való jog védelmével kapcsolatos állásfoglalása. 
tetések sajátos részletszabályait tartalmazza, ehhez csak enyhén hasonló megoldást találunk például Szlovákiában és Csehországban, azonban egy nagy eltérést mutat a szabályozás.

Csehországban kollektív szerződést jogosultak kötni a köztisztviselői szakszervezetek. ${ }^{41}$ A magasabb szintú kollektív megállapodások a kormány és a szakszervezet/szakszervezetek közötti kollektív megállapodásnak minősülnek, és a kollektív szerződés megkötésére vonatkozó vitában a sztrájk a kollektív szerződés megkötésére vonatkozó sztrájknak tekintendő. ${ }^{42}$ Komoly problémát jelent a közszférában a magasabb szintú kollektív megállapodások megkötése, elsősorban a közigazgatásban dolgozók esetében. A szakszervezetek nem képesek magasabb szintû́ kollektív szerződések megkötésére, mert nincs kivel lefolytatni az egyeztető tárgyalásokat, hiszen a munkaadó oldalán nem találunk megfelelő érdekvédelmi szervezetet. ${ }^{43}$

Szlovákiában viszont ennyire sem kiforrott a rendszer, inkább csak a keretek kerültek rögzítésre. 2002-ben a kormány és a szakszervezetek multilaterális kollektív szerződést hoztak létre a köztisztviselők és a közalkalmazottak részére, mely 2003-ban lépett hatályba. 2004. januárban lépett hatályba a 2003. évi DLI. törvény a közalkalmazotti jogviszonyról, és a köztisztviselői jogviszonyról szóló törvény helyébe is új törvény lépett (2003. évi DLII. törvény). A legfontosabb változtatás az volt, hogy ennek hatására módosult a kollektív alkuról szóló törvény is, és lehetôvé tette a közszolgálati jogviszonyokban a kollektív tárgyalások lefolytatását. ${ }^{44} \mathrm{~A}$ közszolgálati jogviszonyokra vonatkozó kollektív szerződések a szakszervezetek konföderációja és az állam között jönnek létre. Az államot a pénzügyminiszter, a belügyminiszter vagy a munkaügyekért felelős miniszter képviseli. ${ }^{45}$ Ezek azonban kifejezetten kollektív szerződések, és mint ilyenek, fogalmilag kizárt, hogy sztrájkmegállapodásként tekintsünk rájuk.

Végezetül érdemes kitérni Olaszország esetére, ahol az Agenzia per la Rappresentanza Negoziale delle Pubbliche Amministrazioni ${ }^{46}$ (a továbbiakban: ARAN), egy közjogi jogi személyiséggel, valamint szervezeti, vezetési és számviteli autonómiával rendelkező szervezet képviseli a közigazgatásban dolgozók érdekeit. Az ARAN végzi a közszektor különféle ágazataiban dolgozókkal kötött kollektív szerződések tárgyalásával és meghatározásával kapcsolatos valamennyi tevékenységet. 2001. május 31-én az ARAN és a bizonyos szakszervezeti szövetségek megállapodást ${ }^{47}$ kötöttek a sztrájk elôtti „lehúlési idő” alatti egyeztetési eljárásokra

41 2014. évi 234. törvény, 82. \$(1) bekezdés.

42 Ld.: https://www.zakonyprolidi.cz/cs/2014-234?text=strike.

43 Kubínková és Wexels-Riser, 2004.

44 Ld.: https://cutt.ly/OxoHyXg (Eurofund: Slovakia - Collective bargaining in the public sector).

45 Uo.

46 A szervezetet az 1993/29. törvényerejû rendelettel hozták létre, majd a 2001/165. és a 2009/150. törvényerejû́ rendeletek kibővítették és megerősítették a funkcióit.

$47 \mathrm{Az}$ eredeti nyelvú szöveg elérhető itt: https://www.aranagenzia.it/attachments/article/201/numero\%2042. pdf. 
vonatkozóan, az alapvetô szolgáltatások körében. ${ }^{8}{ }^{\mathrm{A}}$ megállapodás alapján az egy napnál rövidebb ideig tartó sztrájkot úgy kell véghez vinni, hogy az a lehető legkevesebb kellemetlenséggel járjon a fogyasztók számára, tehát általában a müszak elején vagy végén kell rá sort keríteni. A kollektív szerződések alkalmazzák ezeket az elveket, meghatározva a sztrájk maximális idejét is. Különálló sztrájkok esetén, amelyek ugyanazt a szolgáltatást érintik, a szektor ágazati szerződései meghatározzák a minimális időintervallumot, amelynek el kell telnie az egyik sztrájkakció végrehajtása és a következő kihirdetése között, figyelembe véve a sztrájk okait, a tárgyát, a sztrájkot kihirdető szakszervezeti szintet és az ágazat sajátosságait. Ezt a megállapodást azonban nem a kormányzat kötötte az ARAN-nal, hanem szakszervezeti szinten sikerült rögzíteni a feltételeket.

Németország hasonló megoldást követ, itt - tekintettel arra, hogy a közszférában sztrájktilalom érvényesül ${ }^{49}$-, nincs értelme közigazgatási ágazatra vonatkozó sztrájkmegállapodásról beszélni, ráadásul ebben az államban általánosságban véve beszélhetünk a sztrájk alulszabályozottságáról. A kollektív szerződések viszont nagyon fontos szerepet töltenek be, a szakszervezetek legfontosabb feladata, hogy a kollektív tárgyalásokban kulcsszerepet játsszanak, és részvételükkel sor kerüljön kollektív szerződések megkötésére. A kollektív szerződések ugyanakkor nem tartalmaznak sztrájkjogi rendelkezéseket, hiszen a megállapodások lényegi eleme az is, hogy az idóbeli hatálya alatt munkabéke áll fenn a felek között. A kollektív szerződések közül kiemelendő az ún. Tarifvertrag für den Öffentlichen Dienst (TVöD), amely a közszféra kollektív szerződése. Ennek különös része tekintetében pedig külön kollektív szerződések megkötésére került sor pl. az ápolók esetében (TVöD-Pflegepersonal), a takarékpénztárok munkavállalói esetében (TVöD-Sparkasse) vagy éppen a repülőtéri dolgozók esetében (TVöD-Flughäfen).50

A fenti országokban tehát vannak olyasféle törekvések, amelyek révén a közigazgatásban dolgozók valamiképpen különleges elbírálást kaphatnak az általános törvényi megkötésekhez képest. Vannak ugyanakkor olyan államok, ahol a kérdés egyáltalán nem is merül föl. Jó példa erre Ausztria, ahol nem találunk ilyen jogforrást. Ez a sztrájkjog szabályozatlanságára vezethetô vissza, hiszen sem az osztrák alkotmányban nem találunk kifejezett rendelkezést a sztrájkjogra vonatkozóan, sem külön törvény nem rendelkezik róla, így a köztisztviselők jogállásáról szóló törvény (Beamten-Dienstrechtsgesetz) ${ }^{51}$ sem ismeri a sztrájk fogalmát.

Romániában hasonlót tapasztalunk: sem a közigazgatási ágazatra, sem egyéb ágazatra nem került kidolgozásra egy különálló sztrájkmegállapodás. A közigazgatásban dolgozók - ugyanúgy, mint minden más ágazat - a szociális párbeszédről szóló 2011. évi 62. számú törvény szerint sztrájkolhatnak, tehát az általánosan érvényes szabályok és tilalmak figye-

48 A megállapodásban részes szakszervezeti szövetségek a CISL, a CGIL, az UIL, a CONFSAL, a CISAL, a GIVES

US, a CONFEDIR és a COSMED.

49 Prugberger és Nádas, 2015, 176. o.

50 Ld.: https://oeffentlicher-dienst.info/tvoed/.

51 Gesamte Rechtsvorschrift für Beamten-Dienstrechtsgesetz 1979 (https://cutt.ly/fxoHL50). 
lembevételével szervezhetnek sztrájkot. Mi több, a köztisztviselők státuszáról szóló 1999. évi 188. számú törvény is az általános jogszabályra utalt vissza, és semmiféle külön jogot nem tartott fenn a köztisztviselőknek, utána pedig az ezt felváltó Közigazgatási Kódexről szóló 2019. évi 57. számú sürgősségi kormányrendelet is folytatja ezt az utat.

\section{Központi sztrájkmegállapodások egyéb ágazatokban}

Hazánkban a közszolgálat különböző szegmensei között eltérések vannak a jog gyakorlása terén. A közalkalmazottak esetében a korlátozást a még elégséges szolgáltatások nyújtása valósítja meg. Ennél sokkal kötöttebb a hivatali jogviszonyokban dolgozók helyzete: ${ }^{52}$ a köztisztviselók csak olyan módon és mértékben sztrájkolhatnak, amennyiben ezt a Kormány és a szakszervezetek közötti megállapodás engedi. ${ }^{53}$

Mint láthattuk, a közszférában jelen lévő speciális megállapodások egyfelől inkább kollektív szerződések kategóriájába esnek, másrészt viszont a legtöbb államban nincsenek is ilyen jogforrások, amelyek alapján az állami tisztségviselók is folyamodhatnának érdekérvényesítési eszközökhöz, és akár bizonyos szigorúbb kritériumokat teljesítvén, maguk is sztrájkolhatnának. Más - például stratégiailag jelentôs - ágazatokból vajon nem lehetne analóg módon átvenni néhány megoldást annak érdekében, hogy könnyíthessen a jogalkotó a közszolgálatot teljesítôk helyzetén, ezáltal is erősítve irányukba a sztrájkhoz való jogosultság meglétét? Úgy tûnik, hogy a sztrájkmegállapodás mint jogforrás - bár előnyös megoldásnak tûnik bizonyos speciális esetekben - mégis szinte példa nélküli a nemzetközi összehasonlításban, így ilyesféle analógia alkalmazására egyáltalán nincs mód.

Németországban kifejezett olyan megállapodás, amely általános jelleggel szabályozná egy adott ágazatra vonatkozó szabályokat a sztrájk tekintetében, sem a közszférában, sem más ágazatban nem létezik. Annak lehetősége azonban felmerülhet, hogy egy olyan ágazatban, mint például az egészségügyi szolgáltatás, a sürgősségi ellátásról megállapodás szülessen. Ez az ún. Notdienstvereinbarung. Viszont azt fontos megjegyezni, hogy a sztrájkhoz kifejezetten nem szükséges a megállapodás megkötése, azaz nem magán a megállapodáson van a hangsúly - sokkal inkább kisegítő szerepet tölt be annak érdekében, hogy a sürgősségi ellátás biztosított legyen a sztrájk idején is, és az ennek megfelelő munkarendet bevezessék. ${ }^{54}$

Ausztriában csekély a munkaharci jellegû aktivitás, azon belül is ritkán fordulnak elő sztrájkok, ezért sztrájkmegállapodás semmilyen szektorban nem került megkötésre. Az országban - hasonlóan a német példához - fontos szerepet töltenek be a kollektív szerződések, a munkavállalók $98 \%$-a áll valamilyen kollektív szerződés hatálya alatt. A tárgyalási rendszer

52 Mélypataki, 2018, 141. o.

53 https://www.mkksz.org.hu/html/main/2016/onk_sztrajk/sztrajkmegallapodas19940113.pdf.

54 ArbG Gießen (9. Kammer), Urteil vom 06.03.2020 - 9 Ga 1/20, „45. Erforderlich ist nämlich nicht der Abschluss einer Notdienstvereinbarung, sondern die Einrichtung eines Notdienstes." 
stabilitása érdekében szinte valamennyi kollektív szerződés tartalmazza a „sztrájk tilalma” klauzulát. Amennyiben sztrájkot a kollektív szerződésben foglalt olyan kérdés kapcsán kezdeményeznek, amely kapcsán a szerződés kizárta a sztrájk lehetőségét, az a béke fenntartásának megsértését jelentené. ${ }^{55}$ Emiatt feltételezhető az, hogy nincs szükség külön sztrájkmegállapodás megkötésére Ausztriában. ${ }^{56}$

A kollektív szerződés miatt fennálló békekötelezettség mellett az ún. üzemi alkotmányjogi alapú békekötelezettséggel (betriebverfassungsrechtliche Friedenspflicht) lehet számolni Ausztriában, amely a feleket (munkáltató és munkavállaló) a munkaharctól való tartózkodásra kötelezi. A munka törvénykönyvének 39. \$ (1) bekezdése kimondja az üzemi alkotmány megalkotását, ami a munkáltató és munkavállalók közötti érdekegyensúly megteremtését célozza. Az üzemi alkotmány rendelkezéseit úgy kell tekinteni, mint a múködési béke fenntartását szolgáló eszközöket. ${ }^{57}$ Ettől függetlenül egyéb megállapodást nem ismer az osztrák jogrend sem.

Nemzetközi szinten általánosságban elmondható, hogy a közszférán felül egyéb szektorban, stratégiai ágazatban nem található olyan sztrájkmegállapodás, amelyben a kormányzat rögzítene bizonyos keretrendszert. A különböző ágazatokban a kollektív szerződések jellemzők, azaz elsősorban és szinte kizárólag a szakszervezetek és munkáltatók között dőlnek el a vitás kérdések - a sztrájkhoz való jog pedig általános jogszabályi feltételek szerint gyakorolható. A helyzetből következik, hogy a sztrájkhoz való jog érvényesülése hárompólusú, és nincs átmenet semmilyen irányban: egyfelől létezhet teljes tilalom vagy általános szabályok alapján érvényesíthető szabadság. A szabályozási skála közepén helyezkedik el a limitált joggyakorlás lehetősége, ebben az esetben azonban olyan korlátozás, amelyet külön megállapodásban rendeznek, egyáltalán nem jellemző: a kereteket a jogalkotó inkább magában a korlátozást kimondó jogszabályban állítja fel (ld. pl. Franciaország esetét, ahol a munka törvénykönyve minden részletszabályt tartalmaz a közszféra sztrájkjáról).

55 A munkaharctilalmak között általános tilalomként jelenik meg az ún. kollektív szerződési békekötelezettségből (kollektivvertragliche Friedensplicht) folyó korlátozás, ami kötelmi jogi hatással bíró munkaharci tilalmat ír elő a szerződésben részes felek számára, a szerződés érvényességének ideje alatt (az egyéni munkavállalókra és munkaadókra nem vonatkozik), a szerződésben foglalt kérdések tekintetében. A kollektív szerződés békekötelezettségre vonatkozó rendelkezése csak a kollektív szerződéses partnerekre vonatkozik, ezért más munkáltatókat és munkavállalókat nem kötelezi arra, hogy tartózkodjanak a harcoktól. A felek megállapodhatnak abban, hogy a kollektív szerződésben nem szabályozott területen felmerülő vitás kérdést egy másik kollektív szerződésben rendezik. Ez a korlátozás megegyezik a német munkajogi békekötelemmel. A békekötelezettség megszegése kártérítési igényt is eredményezhet. (Ld. Kiss, 2005, 372. o.)

56 Büttgen, 2018.

57 Berke és Kiss, 2009, 47. 0.; Marhold és Friedrich, 2012, 501-503. o. 


\section{A sztrájk elkerülésének lehetősége}

A sztrájk mindig egyfajta végső eszközként kell hogy jelen legyen a munkavállalói érdekképviseleti palettán. Amennyiben viszont létrejön egy sztrájk a közszférában, a jogszerüségének megítélése könnyen napirendre kerülhet, gondoljunk csak azokra a kérdésekre, hogy megfelelően gondoskodtak-e a szolgáltatás zavartalan múködéséről a szervezők, hogy megengedhető-e a közszférában egy szimpátiasztrájk vagy éppen hogy súlyosabb elbírálás alá esne, mint a sztrájk alapformája, illetve hogy egy esetleges csatlakozó demonstráció - mint a közvélemény figyelmének felkeltésére különösen alkalmas eszköz - milyen mértékben hat negatívan a sztrájk jogszerúségének és hatásainak megítélésre. Amennyiben egy ország nem állít fel speciálisan munkaügyi hatáskörrel rendelkező bíróságokat, sok problémával kell szembenéznie, ahogyan azt például Csehországban vagy Szlovákiában ${ }^{58}$ láthatjuk. Jan Pichrt és Martin Štefko álláspontja szerint a rendszer hátránya, hogy a munkaügyi jogviták rendes bíróságok általi lefolytatása a bíróságok túlterheltsége miatt rendkívül lassú, a költségek figyelembevételével nem is elég olcsó, végül a specializált szemlélet hiánya miatt, különösen az alacsonyabb fokú bíróságok esetében és az ügymegosztás módszerei miatt, nem is eléggé szakszerú, alapos és méltányos a döntéshozatal. ${ }^{59}$

A bírósági eljárások kérdésben azonban nem csupán az vethet fel kérdéseket, hogy speciális vagy általános hatáskörú szerv járhat-e el, hanem az is, hogy több államban van a sztrájkjog gyakorlásának egy kriminalizált aspektusa, azaz súlyos büntetőjogi következménnyel is számolni kell, amennyiben egy sztrájk jogellenesnek minősül. Spanyolországban például a büntetô törvénykönyv szerint börtönbüntetés és súlyos pénzbírság szabható ki az ellen, akiről megállapítják, hogy kényszerített másokat a sztrájk megkezdésére vagy folytatására. A bíróságok hosszú börtönbüntetésekre ítéltek el az elmúlt években szakszervezeti képviselőket, így körülbelül háromszáz munkavállalót tartóztattak le sztrájkban való részvételük miatt. ${ }^{60}$ Hasonló a helyzet Szerbiában, ahol a szakszervezeti tagok legfeljebb három évig tartó börtönbüntetést kaphatnak a jogszabályokkal ellentétes sztrájk megszervezéséért vagy vezetéséért, ha ezzel az életet, az egészséget vagy a vagyont veszélyeztették. Az ILO Egyezmények és Ajánlások Alkalmazásával Foglalkozó Szakértői Bizottsága (Committee of Experts on the Application of Conventions and Recommendations - CEACR) arra figyelmeztet, hogy békés sztrájkban részt vevők ellen semmilyen büntetőjogi szankciót nem lehetne kiszabni.

A bírósági leterheltség csökkentése, valamint a konfliktusok enyhítésének érdekében az alternatív vitarendezési eszköztár szinte mindenhol egyre nagyobb teret nyer magának, így nagy lehetősége van a közszféra munkaügyi vitáinak elrendezésében, ahol - mint lát-

58 Ld.: https://cutt.ly/txoH4Y9 (CMS - Labour law and regulation in Slovakia) és https://cutt.ly/8xoJrYJ (Work areas - Getting The Deal Through - Lexology).

59 Pichrt és Štefko, 2015.

60 Ld.: https://www.epsu.org/article/right-strike-public-sector-europe (Other recent developments and current problems). 
hattuk - a sztrájkhoz aló jog biztosítása nehézségekbe ütközik. A választottbírósági eljárás elterjedt megoldás például Ausztriában, ahol a kollektív munkaügyi konfliktusok esetében a felek szabadon vehetik igénybe az osztrák szövetségi döntôbíráskodást ${ }^{61}$ (Bundeseinigungsamt). ${ }^{62} \mathrm{~A}$ konfliktusban érintett egyik fél kérelmére indul az eljárás, a döntés a felek előzetes írásos nyilatkozata alapján kötelező hatályú a felekre. ${ }^{63} \mathrm{~A}$ sztrájkot megelőző konfliktusok feloldására kiváló példát nyúijthat Norvégia is, ahol a kormány több sztrájkot lezárt és kötelező közvetítést vezetett be az ápolási otthonokban dolgozó ápolószemélyzet, a légiforgalmi pilóták, a kórházak mosodai és vegytisztító szolgáltatásait végző munkavállalók, valamint az olaj- és gázipari dolgozók körében. ${ }^{64}$

Izlandon a kormánynak jogában áll felfüggeszteni bármely folyamatban lévő sztrájkot, és kötelezô választottbírósági eljárást vezethet be, ha a tárgyalások megoldás nélkül kimerültek, és a sztrájk jelentősen károsítja az ország gazdaságát és polgárait. Az ILO Egyesülési Szabadság Bizottsága (CFA) szerint azonban a kollektív tárgyalási folyamat holtpontjának puszta létezése önmagában nem elegendő indok arra, hogy igazolja a választottbírósági eljárás beavatkozását elősegítő kormányt. Hasonlóképpen a Szociális Jogok Európai Bizottsága (ECSR) szerint a sztrájk megszüntetésére elfogadott jogszabályok a légi forgalom vagy az idegenforgalmi ágazat jelentős zavarának elkerülése érdekében, meghaladta az Európai Szociális Charta kereteit. ${ }^{65}$

A konfliktusok feloldásában kiemelt szerepet tehát inkább az olyan szervezetek kaphatnak szerepet, mint Magyarországon a Munkaügyi Tanácsadó és Vitarendező Szolgálat. ${ }^{66}$ Általában azonban úgy tűnik, hogy az egyes államok nem múködtetnek hasonlót: Romániában például a szociális párbeszédről szóló 2011. évi 62. számú törvény IV. fejezete a mediációról és döntốbíráskodásról szól. A fejezet első cikke (175. cikk) szerint a kormány határozata alapján létrejön a munkaügyért felelős minisztérium mellett múködő Kollektív Munkaügyi Konfliktusok Mediáció és Döntőbíráskodási Hivatala (Oficiul de Mediere și Arbitraj al Conflictelor Colective de Muncă), amellyel kapcsolatban ugyan fellelhető a kormányhatározat tervezete, viszont úgy túnik, hogy a jogszabály végül nem készült el, és egyéb aktuális adat sem található a Hivatalról.

61 A köztisztviselők jogállásáról szóló törvény 135a. \$-a rendelkezik a közigazgatási bíróság joghatóságáról. A bíróság joghatósága között nem szerepel a köztisztviselők munkaharci tevékenységének elbírálása.

62 A döntőbíráskodásról szóló törvényt ld.: Verordnung des Bundesministers für Arbeit und Soziales vom 30. Juli 1987, mit der die Geschäftsführung des Bundeseinigungsamtes geregelt wird (Bundeseinigungsamts-Geschäftsordnung - BEA-Geo.) (https://cutt.ly/wxoJQnd).

63 Berke és Kiss, 2009, 50. 0.

64 Ld.: https://www.epsu.org/article/right-strike-public-sector-europe (Government and judicial action to prevent or suspend strike action).

65 Izlandon gyakran sztrájkolnak, és 1985 és 2010 között az izlandi parlament 12 törvényt fogadott el, amelyek számos ágazatban tiltják a sztrájkokat.

66 2015-ben a Nemzeti Munkaügyi Hivatallal együtt gyakorlatilag megszúnt a Munkaügyi Közvetítői és Döntőbírói Szolgálat, helyét a Munkaügyi Tanácsadó és Vitarendező Szolgálat vette át. 
Léteznek azonban előremutató kezdeményezések, mint amilyenre a németországi Lufthansa és a légiutas-kísérők szakszervezete (Unabhängige Flugbegleiter Organisation-UFO) közötti elmérgesedett viszonyban találunk példát: többször próbáltak alternatív vitarendezési eljárásokhoz (arbitrációhoz és mediációhoz) fordulni, mégpedig annak érdekében, hogy a fennálló viszonyt meghaladva sor kerülhessen a kollektív szerződés megkötésére. ${ }^{67}$ Ezen az eseten kívül is ismeretes néhány olyan alkalom, amikor alternatív vitarendezési eljárást hívtak segítségül a kollektív munkaügyi vitában álló felek. 2016. december 23-án a Gewerkschaft Deutscher Lokomotivführer (GDL), azaz a német mozdonyvezetők szakszervezete bejelentette, hogy hat tárgyalási forduló után sikertelennek tekinti a kollektív munkaügyi tárgyalásokat az Arbeitgeberverband der Mobilitäts- und Verkehrsdienstleisterrel (ez tulajdonképpen a mobilitási és közlekedési szolgáltatók munkáltatói szövetsége), és arbitrációs eljárást kezdeményez. Előbbi kinevezte arbitrátorrá Bodo Ramelowot, Thüringia miniszterelnökét, míg utóbbi Matthias Platzecket, Brandenburg korábbi miniszterelnökét. Az arbitráció 2017. január 11-én indult, és 2017. március 9-én zárult le sikeresen. Az említett személyek egyike sem volt a szó szoros értelmében vett arbitrátor vagy mediátor, de köztiszteletben álló személyek lévén sikerült a vitát megoldaniuk pártatlan és semleges ítélkezéssel. Ez azonban a ritka kivételek egyike Németországban. ${ }^{68}$

Rendkívül ritka, hogy a felek harmadik személyt hatalmazzanak fel a vita feloldására. Az alternatív vitarendezési eljárásoknak az a követelménye, hogy mindkét vitában álló fél kívánja és elfogadja azt, hogy a vitát ezen a módon rendezzék, tehát önkéntességen alapul. Ez azonban rendkívül kivételes, mégpedig annak köszönhetően, hogy a szakszervezetek erős pozícióval rendelkeznek Németországban, s nem érzik annak szükségességét, hogy harmadik személyek segítségét igénybe vegyék. Továbbá, arra is visszavezethető az alternatív vitarendezési eljárások kivételessége a kollektív munkaügyi vitákban, hogy az autonómiaelv az egyik legfontosabb alapelve a kollektív tárgyalásoknak, amely elv pedig a Grundgesetzben gyökerezik. ${ }^{69} \mathrm{~A}$ rendszer legnagyobb hibájának és az alternatív vitarendezési eljárások fokozottabb igénybevétele elôtti akadálynak egyértelmúen az önkéntesség tekinthetô, amelyet számos szakértő megfogalmazott már. ${ }^{70}$

A kollektív tárgyalások területén Ausztriában is találhatunk érdekes jellegzetességet, hiszen itt a közszféra és magánszféra esetében eltér a kollektív tárgyalás menete. A köztisztviselők hivatalosan nem vehetnek részt ilyen egyeztetéseken - a munka törvénykönyve 4. \$-a ételmében (Arbeitsverfassungsgesetz-ArbVG) ${ }^{71}$ a munkavállalók és munkáltatók törvényes érdekképviseleti szerveit, illetve a 7. \$ szerint a közjogi jogi személyeket illeti meg a kol-

67 Ld.: https:// www. tagesschau.de/wirtschaft/tarifkonflikt-flugbegleiter-lufthansa-101.html.

68 Euwema et al., 2019, 99. o.

69 Euwema et al., 2019, 100. 0.

70 Euwema et al., 2019, 111. o.

71 Bundesgesetz vom 14. Dezember 1973 betreffend die Arbeitsverfassung. Ld.: https://www.ris.bka.gv.at/GeltendeFassung.wxe?Abfrage $=$ Bundesnormen $\&$ Gesetzesnummer $=10008329$. 
lektív tárgyalás joga, a köztisztviselőkről szóló törvény pedig nem rendelkezik a kollektív tárgyalás jogáról ${ }^{72}$ - a gyakorlatban a Közszolgálati Szakszervezet (Gewerkschaft Öffentlicher Dienst - GÖD) és a Younion ${ }^{73}$ szervezet folytat tárgyalást a köztisztviselők és a közszektor munkavállalóinak bére és munkafeltételei kapcsán. ${ }^{74} \mathrm{~A}$ Munkaügyi Kamara (Arbeitskammer) - mint törvényes munkavállalói érdekképviseleti szerv - tárgyalófélként nem vehet részt a kollektív tárgyalások során, a tárgyalási jogot a szakszervezetek gyakorolják, de támogató szereplőként részt vehet, melynek keretében információkat nyújthat makrogazdasági fejleményekről, és adatokat szolgáltathat az ipar fejlődése kapcsán. ${ }^{75}$

Szlovákiában - bár munkaügyi vitában csak a bíróság hozhat döntést ${ }^{76}$ - mégis intézményesített gyakorlata van annak, hogy miként állapodhatnak meg a felek informális eljárás keretén belül állami szerv segítségével. A Nemzeti Munkaügyi Hivatal a jogszabályok betartását és végrehajtását ellenőrzi, amennyiben azonban a kollektív munkaügyi vitában érintett felek nem tudnak egymással megállapodni, a Hivatalhoz fordulhatnak, amelynek proaktív szerepe van, annak érdekében, hogy elősegítse a felek között a megállapodás létrejöttét. Kötelező érvényú határozatot vagy döntést nem hozhat, bírságot azonban kiszabhat, ha úgy ítéli meg, hogy a munkáltató jogszerútlen gyakorlatot folytat. A szlovák gyakorlat azért előremutató, mert a közszférában az állam integritásának megőrzése érdekében sokkal előnyösebb lehet egy állami szerv segítségét igénybe venni alternatív vitarendezés érdekében, mint bármely külső minőségben eljáró szakértőét.

A fentiekből kitûnik tehát, hogy a közszférában a sztrájkjog gyakorlásának sok esetben komoly korlátai vannak - ennek elsősorban a szolgáltatások zavartalan fenntartása a célja -, mégis van arra törekvés, hogy a teljes kizárás helyett inkább észszerú korlátozásokkal éljen a jogalkotó. Amennyiben pedig a követelményeknek nem felel meg egy tervezett sztrájk, egyre szélesebb körben állnak rendelkezésre lehetőségek, hogy a felmerülő vitás kérdéseket a sztrájknál akár hatékonyabb módon rendezzék a felek.

Bár az esetek túlnyomó többségében erre formális úton csak a bíróság előtt van lehetőség, a modern vitarendezés sok helyütt alkalmat kínál alternatív megoldások igénybevételére is. Ami a bíróságokat illeti, elmondható, hogy komolyabb jogérvényesítési probléma azon országok esetében merül föl, ahol nincs dedikált bírósága a munkaügyi pereknek, és általános hatáskörú bíróság előtt kénytelenek a felek eljárni - a munkajogi problémák speciális felkészültséget igényelnek, ezen belül is a közszféra igen érzékeny területnek számít, azaz nem közömbös, hogy az eljáró döntéshozó mennyire ismeri a felmerülő speciális kérdéseket és érdekellentéteket.

72 Marhold és Friedrich, 2012, 425-426. o.

73 A Younion az önkormányzati munkavállalók, valamint a múvészek, média, sport és szabadfoglalkozásúak egyesülete.

74 Glassner és Hofmann, nincs évszám, 33-34. o.

75 Glassner és Hofmann, nincs évszám, 35-36. o.

76 Kahancová, Martišková és Sedláková, 2019. 
Az alternatív eljárásokat illetően azonban a közszféra területén is lassú haladás tapasztalható, hiszen több jogrendszerben kialakítottak már olyan szervezeteket, amelyek a különleges körülmények között is képesek közvetítői vagy döntőbírói szerepet betölteni, az eredményes tárgyalásokkal pedig megakadályozható a nemkívánatos szolgáltatáskiesés.

\section{5. Összefoglalás}

A sztrájk gyakorlása általában a munkavállalók egy végső eszköze arra az esetre, amikor már tényleg nem látnak más lehetőséget akaratuk érvényesítésére. A közszférában általános jelenség az a jogtechnikai álláspont, amely szerint egy közszolgálatot ellátó személy ne érvényesítsen érdeket munkáltatójával, azaz az állammal szemben.

Érdemes azonban tudatosítani, hogy a munkavállalói akarat érvényesítése elsősorban a munkafeltételekre, de legfőképpen a bérekre terjed ki. Tény, hogy az egyes országokban eltérő rendszer alakult ki arra nézve, hogy mennyire engedik a közszolgálati dolgozóknak a sztrájkra lépés lehetőségét. Fontos ellenpont lehet ugyanakkor a tiltás mellett érvelő országok számára, hogy a közszolgálatban megismert és megkövetelt lojalitásnak teljesen más az iránya, mint a munkabérrel összefüggő kérdéseknek. Attól, hogy egy hivatalnok nem elégedett a fizetésével, aminek hangot is ad, nem jelenti azt, hogy a hüséget, amire felesküdött, megsértené. Amint Mélypataki Gábor hangsúlyozza, ${ }^{77}$ a sztrájk mindig egy folyamat végét jelenti.

A közszolgálati alkalmazottak a német terminológiát követve a munkaviszonyhoz képest magasabb szintû́ szolgálatot teljesítenek, hiszen akár közvetlen, akár közvetett formában az állam mint munkáltató irányítása és ellenőrzése alatt végzik a munkájukat, amely kötöttségekkel jár. Ebben a leszúkített mozgástérben sokszor a munkaügyi kapcsolatok érvényesítésére nincs lehetőség, vagy csak igen korlátozott formában van. Az ILO és az Európa Tanács elsősorban a rendőrséget és a fegyveres erőket emeli ki a sztrájkjog jogosultjainak köréből, azonban államonként eltérhet, hogy ezen személyi körökhöz még mely foglalkoztatási ágazatokat csatolják hozzá.

A korlátozással érintett szektorokban - amint az Magyarországon is megfigyelhető -magasabb az egyéb kollektív érdekérvényesítő akciók aránya, így többek között tüntetések, nyílt levél, aláirásgyújités jellemzi az érintett személyi kört. A sztrájk elkerülésének lehetőségét is láthatjuk ezen elterjedt eszközökben, amelyek segítenek hallatni a foglalkoztatotti állomány hangját, ám mégsem érintik a munkavégzést olyan drasztikusan, mint maga a sztrájk. Természetesen kiegészító eszközként egyre népszerúbbé válnak az alternatív vitarendezési eljárások is, amelyek munkaharceszköz gyakorlása nélkül teszik alkalmassá a feleket a vitás kérdések kezelésére és a megfelelő kompromisszumok megtalálására.

77 Mélypataki, 2018, 127. o. 


\section{Irodalomjegyzék}

BAlanescu, D. (2019) 'The right to strike in the public sector - Czech Republic', EPSU, 2019 [online]. Elérhető: https://cutt.ly/9xok3bM

BeAuregard, M. DE (2019) 'Die Rechtsprechung zum Arbeitskampfrecht in den Jahren 20162018', NZA-Rechtsprechungs-Report Arbeitsrecht, 24(12) 625-629. o.

BERKE, GY., KISS, GY. (2009) 'A sztrájkjog szabályozásának lehetőségei a közszolgáltatások területén' / 'A sztrájk korlátozása közüzemeknél és stratégiai vállalatoknál - külföldi példákkal', Pécsi Munkajogi Közlemények, 2(2) 29-73. o.

BERKI, E. (2009) 'Az elégséges szolgáltatás problémája’ Pécsi Munkajogi Közlemények, 1(2) 111-118. 0.

BERKI, E. (2019) Munkaügyi akciók 2010 és 2019 között Magyarországon, különös tekintettel a sztrájkokra. Friedrich Ebert Stiftung Magyarország. Elérhető: http://library.fes.de/pdf-files/ bueros/budapest/15596.pdf.

Birklbauer, A. (2000) 'Die Strafbarkeit von arbeitsrechtlichen Konflikten', Das Recht der Arbeit, 50(3) 228-231. 0.

Büttgen, N. (2018) The right to strike in the public sector, Austria. European Trade Union Institute. Elérhető: https:/www.epsu.org/sites/default/files/article/files/Austria\%20-\%20 Right\%20to\%2ostrike\%2oin\%2opublic\%2osector.pdf.

Euwema, M. C., Medina, F. J., García, A. B., Pender, E. (szerk.) (2019) Mediation in Collective Labor Conflicts. Springer International Publishing. Elérhető: https://link.springer.com/ content/pdf/10.1007\%2F978-3-319-92531-8.pdf.

Glassner V., HofmanN, J. (nincs évszám) 'Austria: from gradual change to an unknown future' in Collective bargaining in Europe. Elérhető: https://www.etui.org/sites/default/ files/CB1-Chapitre\%2B2.pdf.

Kahancová M., MartišKová, M., SedlákovÁ, M. (2019) 'Slovakia: between coordination and fragmentation' in Müller, T., Vandaele, K., Waddington, J. (szerk.) Collective bargaining in Europe: towards an endgame. Volume I, II, III and IV. Elérhető: https://www.etui. org/sites/default/files/CB\%20Vol\%20III\%20Chapter\%2025.pdf.

KAJTÁR, E. (2011) Magyarsztrájkjoga nemzetköziésazeurópaiszabályozásfényében. PhD-értekezés. Pécs. Elérhető: https://ajk.pte.hu/files/file/doktori-iskola/kajtar-edit/kajtar-edit-vedesertekezes.pdf.

KIss, Gy. (2005) Munkajog. Budapest: Osiris Kiadó.

Kubínková, M., WeXels-Riser, N. (2004) National Labour Law Profile: The Czech Republic. ILO [online]. Elérhető: https://cutt.ly/cxoA9Ip

LÁpossy, A., ZELLER, J. (2009) 'A sztrájkhoz való jog mint alkotmányos alapjog: tézisek és dilemmák', Pécsi Munkajogi Közlemények, 1(2) 98-106. o.

MARHOld, F., FrIEDRICH M. (2012) Österreichisches Arbeitsrecht. Bécs: Springer. Elérhető: https://ink.springer.com/book/10.1007/978-3-211-99405-4. 
MÉlyPataki G. (2018) 'A közszolgálati sztrájkjog alapvonásai nemzetközi összehasonlításban', Publicationes Universitatis Miskolcinensis. Sectio Juridica et Politica, 1(36), 126-143. o.

MERLEY, N. (2017) 'Le point de vue de l'administrativiste : la jurisprudence administrative facteur de fragilisation du droit de grève dans les services publics' in Crouzatier-Durand, F., Kada, N. (szerk.) Grève et droit public, 70 ans de reconnaissance. Toulouse: Presses de l'Université Toulouse. 1 Capitole. Elérhető: http://books.openedition.org/putc/1049.

PAJCSICSNÉ CsórÉ, E. - VARGA É. Cs. (2009) 'A rendvédelmi dolgozók sztrájkhoz való joga' Pécsi Munkajogi Közlemények, 2(2), 91-98. o.

PICHRT J., ŠTeFKo, M. (2015) 'Alternatív vitarendezési eljárások a cseh munkaügyi kapcsolatokban', Magyar Munkajog, 1(2) [online]. Elérhető: http://epa.oszk.hu/02500/02566/00002/ pdf/EPA02566_munkajog_2015_1_108-117.pdf.

Prugberger T., NÁdAs Gy. (2015) Európaiés magyarösszehasonlitó kollektív munkajog. Budapest: Wolters Kluwer.

RÁcz Z. (2012) 'A sztrájkjog megítélése az Alaptörvény tekintetében', Publicationes Universitatis Miskolcinensis Sectio Juridica et Politica, 2(30), 569-575. o.

StEFAN,C.,WIEBKE,W.(2009)Betterdefendingandpromotingtradeunionrightsinthepublicsector. PartII: Countryreports. Report108,Brussels:ETUI.101.Elérhető:https://www.etui.org/Publications2/ Reports/Better-defending-and-promoting-trade-union-rights-in-the-public-sector.

ŚWiątkowski, A. M. (2018) 'Strike Restrictions in Contemporary Polish Labour Law', Hungarian Labour Law E-Journal, 1(5), 57-75. o.

ZemplÉNYI, A. (szerk.) (2010) ‘Sztrájkjogi projekt', ÁJOB Projektfüzetek, 2010/4 [online]. Elérhető: https://cutt.ly/SxoDGZp 